PRODUCTION

ENGINEERING

ARCHIVES
2016, Vol. 12, No. 3, pp 34-37

ISSN 2353-5156

ISSN 2353-7779 (print version)

(online version)

\title{
Article
}

history:

Received: 10.09.2016

Accepted: 20.09.2016

Online:

30.09.2016

Available online on: http://www.qpij.pl

2013

\section{Tendencies in the development of modern sacral architecture on the example of the Archdiocese of Czestochowa}

\author{
Aleksandra Repelewicz ${ }^{1}$ \\ ${ }^{1}$ Czestochowa University of Technology, Faculty of Civil Engineering, ul. Akademicka 3, 42-200 Czestochowa, Poland, phone: 343250944 \\ mail: arepelewicz@bud.pcz.czest.pl
}

\begin{abstract}
Trends in development of 1945-2015 sacral architecture in Poland are presented in the paper. The issue is analysed on the example of Czestochowa Archdiocese churches. The analyses are based on the authors' own researches conducted between $2010-2015$. Churches drafts, information about estimate year outlays and data from parish records were collected from each parish and considered. The author especially focuses on the buildings from the $70 \mathrm{~s}, 80 \mathrm{~s}$ and $90 \mathrm{~s}$, which are not suited to the current needs of parishes. Visible trend to build very large sacral objects in the $70 \mathrm{~s} / 80 \mathrm{~s}$, due to uncertainty of getting further building permissions is described. Multifunctional buildings, containing catechetical classrooms erected as a result of restrictive government regulations on the construction of churches in the 80 s and 90 s are presented.

The author emphasizes that in the XXI century, smaller and better adapted to the needs of the local community church buildings are created. These facilities are in addition more energy efficient and built with materials of better quality.
\end{abstract}

Key words - sacral architecture, church buildings, Archdiocese of Czestochowa

\section{Introduction}

The development of sacral architecture, especially Roman Catholic churches, in post-war Poland correlates strongly with the changing political situation. Between the end of World War II and the fall of communism, a period of stagnation had been visible. The improvement has appeared after 1989. Nowadays no obstructions in designing and building churches are imposed. Sacral objects are considered as any other investments. After 2000, the dynamics of sacral objects erection has decreased considerably, due to the suffice of them. 3635 new churches were built in Poland during described 70 years. (BIQDATA.WYBORCZA.PL)

In XXI century, decreasing number of parishes in Europe has been noted. However, in Poland, during two decades 1990-2010, the number of parishioners per 1 parish decreased from 3682 to 3162 , the total number of parishes increased by 1737 (17.6\%). This phenomenon is described as unique among European countries (THE CATHOLIC CHURCH IN POLAND. 2014).

There is a lack of research on the development of sacral post-war architecture in literature. Those churches requires detailed cataloguing, to show a remarkable influence of political situation on the investments. Creating a monograph about post-war sacral architecture in Poland should be provided interdisciplinary, with architects, historians and constructors participation.

The paper illustrates situation among Czestochowa Archdiocese, but further investigations among other Dioceses should be provided to compare and contrast the impact of political situation on the architecture within the country. 


\section{Methodology of research}

The analyses are based on the authors own researches conducted among 2010-2015 in the Archdiocese of Czestochowa. Churches drafts, information about estimate year outlays and data from parish records were collected from each parish and considered. Interviews with parsons were conducted due to obtain information about number of faithful and usefulness of each part of construction. The total area of sacral buildings, the area of church used strictly for religious rituals, the number of active faithful and the area per one faithful were analyzed.

\section{Results and discussion}

There were 7555 church buildings throughout the whole country in 1945. During the first 25 years after the war, 333 sacral objects appeared (Fig. 1).

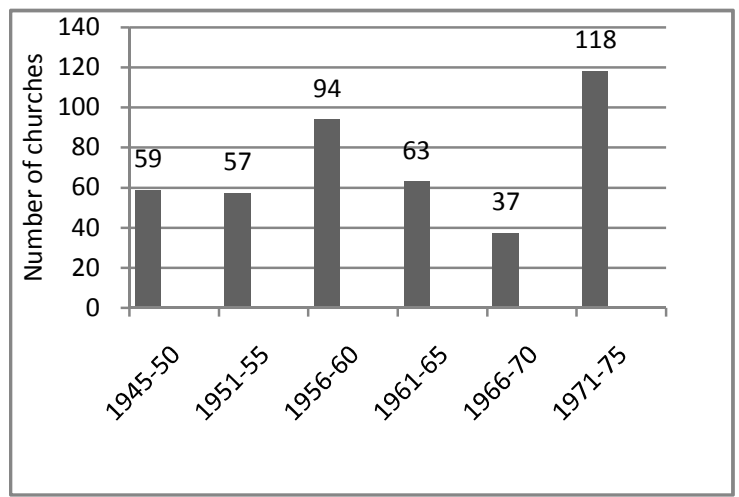

Fig. 1. Number of new churches erected during first three decades after the World War II in Poland.

Source: author's own research

Insufficient number of new erections can be explained by the tough policies directed against the church by the communistic state government. Requirements in creating a new sacral object had been stringent deliberately to obstruct the erections. In years 19561960, thanks to the changes in the political situation, transitory improvement has been noted. After that short period, the restrictions were reintroduced (SIWEK S. 1986; BIELECKI K. KARCZ J. 1979).

In the years 1970-1980 the number of churches under construction increased. Most churches created in the 80s were multifunctional objects. Those days the easiest way to obtain the permit was to project a chapel with area of less than $250 \mathrm{~m}^{2}$. A catechetical objects with usable area less than $600 \mathrm{~m}^{2}$ were also accepted much easier than earlier.
However for larger churches it was still difficult to get permission. There are many sacred buildings with usable area over $1000 \mathrm{~m}^{2}$ and even more whose area exceeds $1500 \mathrm{~m}^{2}$, erected in the $80 \mathrm{~s}$. Most of them were built between 1984 -1992. In 1988 - 173 churches with an area of over $1500 \mathrm{~m}^{2}$ and 66 buildings larger than $1000 \mathrm{~m}^{2}$ were erected. This phenomenon can be explained by the stiff history of restrictions.

When building permission was given after years of failure to receive it, the Archbishop often decided to build an inadequately huge object. The prospects of receiving further permissions were uncertain. (BIQDATA.WYBORCZA.PL; ARCHITEKTURA7DNIA.PL)

The Archdiocese of Czestochowa is divided into four pastoral districts: Czestochowski, Radomszczanski, Wielunski and Zawiercianski. In the Czestochowski region of the Archdiocese of Czestochowa, 85 new church buildings have been erected since 1945 (Fig.2)

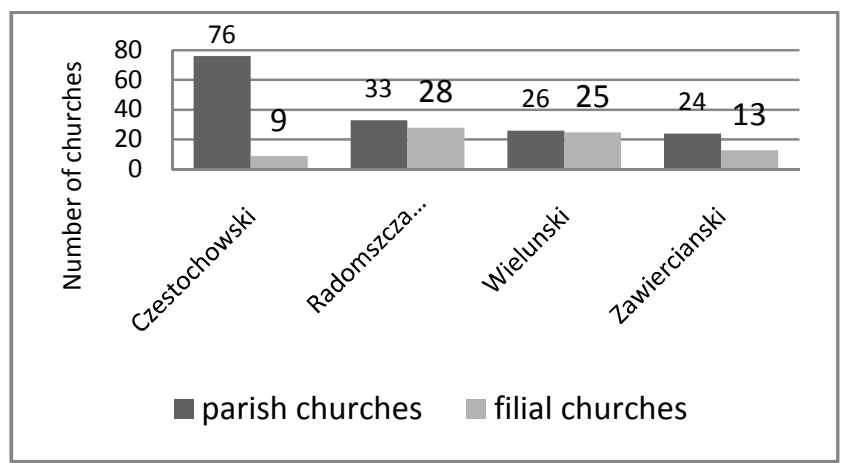

Fig. 2. Number of new churches erected in years 1945-2015 in Archdiocese of Czestochowa

Source: author's own research

Filial churches are objects situated within the parish but which are not the main church building.

In the Wielunski region there are 51 new church buildings in total. The Radomszczanski region comprises 61 church buildings erected after World War II. The Zawiercianski pastoral region has had the least number of churches built since 1945 - 37 . Generally exist 234 church buildings which were erected between 1945 and 2015.

There is a significant number of churches that are currently too large for the needs of contemporary parishes in Poland. As large, author means:

- one-story objects with a surface area over $1000 \mathrm{~m}^{2}$ or

- two-story objects with a surface area of ground floor over $900 \mathrm{~m}^{2}$.

The Archdiocese of Czestochowa has 8 buildings which fall into this category (Tab.1). Five of them are two-story. 
Aleksandra Repelewicz, Tendencies in the development of modern..., Vol. 12(3) 2016

Table 1. Data for large churches of Archdiocese of Czestochowa

\begin{tabular}{|c|c|c|c|c|c|c|}
\hline No. & Name of the church & Location & $\begin{array}{c}\text { The surface } \\
\text { area of the } \\
\text { ground floor }\end{array}$ & $\begin{array}{c}\text { Number } \\
\text { of levels }\end{array}$ & $\begin{array}{c}\text { Number of parish } \\
\text { inhabitants/ active } \\
\text { faithful }\end{array}$ & $\begin{array}{c}\text { Years of } \\
\text { construction }\end{array}$ \\
\hline 1. & Church of St. Adalbert & Czestochowa & $940 \mathrm{~m}^{2}$ & 2 & $10000 / 4000$ & $1978-1985$ \\
\hline 2. & Church of Our Lady Victorious & Czestochwa & $1060 \mathrm{~m}^{2}$ & 2 & $8000 / 3200$ & $1975-1985$ \\
\hline 3. & Church of St. Stanislaus & Czestochowa & $1370 \mathrm{~m}^{2}$ & 2 & $6000 / 2400$ & $1983-2000$ \\
\hline 4. & Church of St. Albert Chmielowski & Czestochowa & $1020 \mathrm{~m}^{2}$ & 2 & $1800 / 720$ & $1981-2001$ \\
\hline 5. & $\begin{array}{c}\text { Church of Sacred Heart of Jesus } \\
6 .\end{array}$ & Czestochowa & $1100 \mathrm{~m}^{2}$ & 2 & $7962 / 3185$ & $1978-1990$ \\
\hline 7. & $\begin{array}{c}\text { Church of blessed Ursula } \\
\text { Ledóchowska }\end{array}$ & Czestochowa & $1300 \mathrm{~m}^{2}$ & 1 & $7500 / 3000$ & $1987-1999$ \\
\hline 8. & $\begin{array}{c}\text { Church of Virgin Mary Queen of } \\
\text { Poland }\end{array}$ & Zawiercie & $1000 \mathrm{~m}^{2}$ & 1 & $9000 / 3600$ & $1974-2000$ \\
\hline
\end{tabular}

Source: autor's research

Needs of a contemporary parish can be estimated by the number of active congregation. In Poland, the percentage of people participating in a holy mass is recorded at $40 \%$. Therefore the number of churchgoers is much smaller than the number of all parish inhabitants (THE CATHOLIC CHURCH IN POLAND. 2014).

In the Archdiocese of Czestochowa in the years 1990-2010 the number of parishes increased from 282 to 311 (THE CATHOLIC CHURCH IN POLAND. 2014). Most sacral objects are fitted to the congregation, erected using modern materials, with adequate insulation and durability. Suitable energy efficiency of new-erected sacral buildings is being observed (REPELEWICZ A. 2014). Investors decide to apply layered walls, which, according to the author's study, practically did not occurred formerly. There are modern energy-saving windows and heating systems with high efficiency too. The system of quality control during the construction of religious facilities improved significantly. The quality control structures have been reformed by Church authorities (ULEWICZ R. 2013).

There are more environmental educated engineers in our society at present, so the suitable energy efficiency of the sacral buildings in projecting phase may be emphasised (ČEKANOVÁ K., PAULIKOWÁ A. LESTYÁNSZKA ŠKURKOVÁ K. 2015).

Examples of newly erected objects may be the following: Church of St. John Sarkander in Czestochowa (Fig. 3) is used by the community of 1320 parish inhabitants. It was built in 2002-2007. The total area of the building is $330 \mathrm{~m}^{2}$. The church has a relatively small cubic capacity. It was built with modern construction materials having good thermal insulation. It also has an interesting outside form.

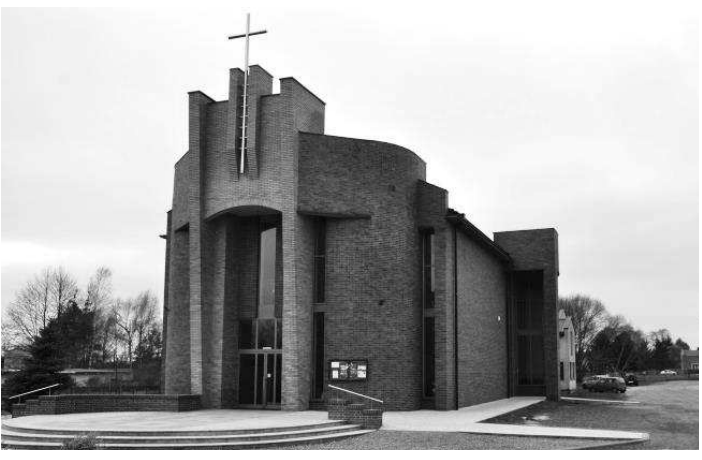

Fig. 3. Church of John Sarkander in Czestochowa Source: author's own photography

Holy Redeemer Church in Blachownia. is used by the community of 1400 parish inhabitants. It was built in 1995-2000. The total area of the building is $224 \mathrm{~m}^{2}$. The church has an extraordinary low cubic capacity in comparison with other religious buildings (REPELEWICZ A. 2015).

Obviously, there are also some examples of currently constructed large buildings in the Archdiocese of Czestochowa. Sanctuary of the Blood of Christ and the Sanctuary of Divine Mercy in Czestochowa are such an examples. These are not the parish churches, but the objects of worship for a greater number of followers. In communism, relatively the easiest way to get permission for building was to design it as catechetical objects with usable area less than $600 \mathrm{~m}^{2}$. At that time, a lot of such objects were built in Poland. In the design phase lots of catechetical classrooms and auxiliary rooms with 
a small chapel for mass were shown on drawings and presented for approval at state planning offices. Having obtained permission the object was erected differently from the designed. Often parts of the walls were removed, enlarging the chapel and reducing the number of catechetical halls. Sometimes the external dimensions of the entire facility were enlarged too. These actions has had an unexpected results. The external form of the church is often random. As a result of contemporary changes in people's mentality, there is a need for a church to be located near in the proximity of one's house. Travelling to a distant parish, which was formerly an accepted norm, has become a waste of time. Therefore, new sacral buildings are still erected. However, the newly designed churches significantly differ from those raised in the twentieth century. They are much more suited to the current needs of parishes. What is more, contemporary parishes are not created as a multifunctional facilities, since the transfer of religious education to schools has been done. Now religious education in Poland takes place in schools, and catechetical classrooms located among sacral buildings are not used for their original purposes. Some of them are generally not used at all. A positive example is Church of Visitation Virgin Mary in Czestochowa. A catholic high school and a middle school are located in the catechetical part of the church. When the area of parishes has been reduced and divided into different parts, huge sacral buildings are not fitted to the number of parishioners. The costs of their maintenance (heating, lighting, ongoing maintenance) and repairs significantly exceeds the capabilities. This is a serious problem for the administrators of these facilities and their parishioners. Finding a way out of this situation is a major challenge for both the church authorities and local communities. It is necessary to look for opportunities to use these huge spaces for other purposes, which would not be contrary to the fundamental role of a parish church.

These problems may intensify with aging and deteriorating of the buildings. A further reduction in the number of parishioners as a result of demographic changes and the secularization of society cannot be excluded.

\section{Summary}

A real shortage of church buildings after communistic times caused a huge increase in church investment in the $80 \mathrm{~s}$ and 90s. Society needs were answered by construction of churches which was dictated sometimes by ideological considerations. There are a significant number of churches that are very large and they are currently too large for the needs of contemporary parishes. Also catechetical objects with usable area less than600 $\mathrm{m}^{2}$ are left ver from the communist era. Catechetical parts of these objects are currently unused or used for other purposes.

On the basis of observations of changes in projects and the realization of examined churches over time, it can be noticed that today's objects are smaller, and adjusted to the number of parishioners. A tendency to apply modern building materials and to energy efficient designs is also noticeable.

\section{Literature}

1. BIELECKI K. KARCZ J. 1979. old and new churches. sacral construction in the 35-year period. (kościoły stare i nowe. budownictwo sakralne w 35-leciu, in polish), za i przeciw nr 37. pp.1,6,17.

2. ČeKanová K., PAulikowÁ A. LestyánszKA ŠKURKOVÁ K. 2015. optimisation of quality in environmental education by means of software support. production engineering archives, no 4, pp. 1316.

3. REPELEWICZ A. 2014. thermal insulation of sacral objects under the new rules. (izolacyjność termiczna obiektów sakralnych w świetle nowych przepisów, in polish) budownictwo o zoptymalizowanym potencjale energetycznym. częstochowa 1(13) pp. 101-107.

4. REPELEWICZ A. 2015. geometry of sacral objects. (geometria obiektów sakralnych, in Polish). Chapter in the monograph „Geometria w budownictwie lądowym" edited by r. szopa and a. repelewicz. politechnika częstochowska Publisher. pp. 37-73.

5. SIWEK S. 1986. Sacral architecture - continued. (Budownictwo sakralne - ciąg dalszy, in Polish) tygodnik powszechny no. 2/1986.

6. UlEWICZ R. 2013. Effectiveness assessment of functioning of quality assurance system production engineering archives, No 1, pp 38-40.

7. THE CATHOLIC CHURCH IN POLAND. 1991-2011. 2014. publisher cso. warsaw. (kościół katolicki w Polsce, in polish).

8. biqdata.wyborcza.pl; (30.09.2016).

9. architektura7dnia.pl (30.09.2016).

10. kuriaczestochowa.pl (30.09.2016). 